\title{
Performance Evaluation of Modulation strategies for Dual Active Bridge Multiport DC-DC Converter
}

\author{
Dr.R.Seyezhai* \\ *Associate Professor, Department of EEE, SSN College of Engineering, Chennai
}

\begin{abstract}
Multiport DC-DC converters have recently gained attention to interface more than one power source with a load. By using these converters, it is possible to diversify the energy sources so that the power system availability can be increased. Furthermore, utilization of renewable and alternative sources can be increased by combining units with different technologies or by integrating energy storage to feed the load when the power sources are unavailable. This paper proposes a dual active bridge DC-DC converter for renewable energy applications. It is a DC-AC-DC converter which allows energy transfer between the source and the load. The performance of the converter will be analyzed by comparing various modulation strategies like phase shift, triangular and trapezoidal methods. The design of high frequency transformer has been discussed. The proposed topology is verified by simulation results.
\end{abstract}

\section{Keywords}

Multiport DC-DC converter, dual active bridge, phase shift, triangular and trapezoidal

\section{INTRODUCTION}

In recent years, a lot of emphasis has been made on renewable energy resources. Although there are a numerous advantages, renewable energy resources have certain drawbacks. They are basically intermittent in nature. But modern energy applications demand constant voltage at constant frequency. This paper proposes a multiport DC-DC power converter circuit that can deal with the intermittent nature of renewable energy. The advantage of multiport DC-DC converters are high efficiency, less component count, compact, low cost, reduced filter size and improved performance compared to the usage of several independent converters for renewable energy source[1]. Several types of multiport converters have been discussed in the literature. This paper focuses on a dual active bridge DC-DC converter which is a buck and boost bidirectional converter isolated by a high frequency transformer. Various modulation strategies have been discussed for the dual active bridge DC-DC converter. The performance parameters have been analyzed in terms of output voltage ripple and switching losses. A suitable high frequency transformer is designed. Simulation studies have been carried out using MATLAB to verify the theoretical results.

\section{OPERATION OF DUAL ACTIVE BRIDGE DC-DC CONVERTER}

A dual active bridge (DAB) converter with high power density and soft switching operation is proposed as a bi-directional DC to DC interface to convert electric energy between a low voltage battery and a high voltage DC bus [2,3]. It is a DC-AC-DC converter which allows energy transfer between the source and the load. It is a buck and a boost bidirectional converter isolated by a high frequency transformer. The source side and the load side both are full- bridge circuits, operated at a fixed frequency. The two full bridges are connected via a high frequency transformer. Full bridge circuits have minimal voltage and current stresses in the devices and minimum VA rating of the transformer[4]. High frequency transformer can integrate different voltage levels with the turn ratio of the transformer. It also provides electrical isolation, which may be required by the industry standard. Finally, the leakage inductor of the transformer can be used as an energy transfer element. In every cycle, a small fraction of energy from the source is stored in this leakage inductor before it is transferred to the load. The inductance can be added by using external inductors connected in series with the transformer. Fig.1 shows the circuit for $\mathrm{DAB}$ converter. 


\section{Dr.R.Seyezhai / IOSR Journal of Engineering (IOSRJEN) \\ www.iosrjen.org}

\section{Vol. 1, Issue 1, pp. 077-083}

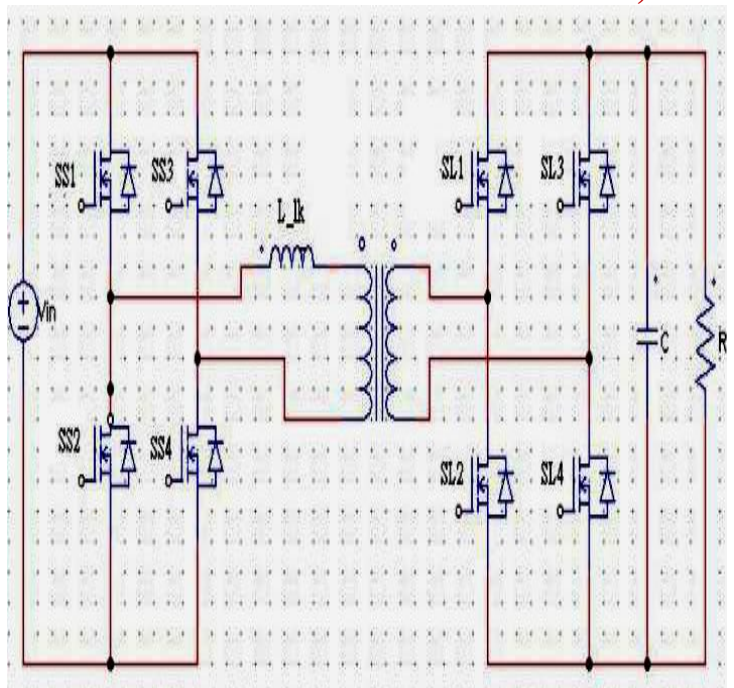

Figure .1 Dual active bridge DC-DC Converter

The switches of the DAB circuit are operated at a constant frequency. The switches are operated at a fixed frequency and with a fixed duty cycle of $50 \%$.

\section{III.MODULATION STRATEGIES FOR DAB DC-DC CONVERTER}

Three types of modulation strategies have been analyzed for DAB DC-DC converter [5.6,7] as shown in Fig.2.

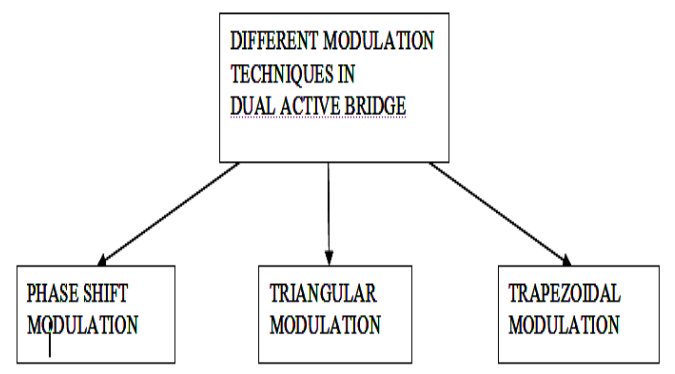

Fig.2 Types of modulation techniques for DAB

\section{A. Phase Shift (PS) modulation}

Phase shift modulation is the widely used technique in dual active bridge converter. For phase shift operation, rectangular transformer voltages $\mathbf{v}_{T 1(t)}$ and $v_{T 2(t)}$ with switching frequency $f_{S}$ and phase shift $\phi$ are applied to the transformer and the converter inductance $L$. The power transfer is controlled by the phase shift angle $\phi$. The higher the phase difference, the higher is the power transferred. It is given by the equation,

$$
P=\frac{V_{1} V_{2}}{n} \emptyset \cdot(\pi-\emptyset) / 2 \pi^{2} f_{s} L
$$

The switching pattern for phase shift modulation is shown in Fig.2.

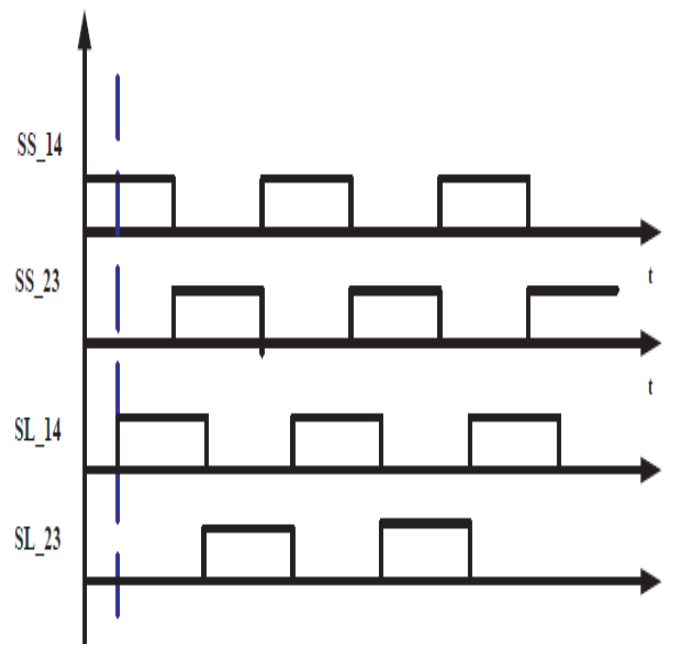

Fig.2 Gating pattern for phase shift Modulation

The advantages of PS method are:

- Phase shift modulation is very simple to implement.

- It is possible to use half bridge circuits to generate the high frequency transformer voltages $v_{T 1(t)}$ and $v_{T 2(t)}$.

- Less number of power electronic devices.

The disadvantages of PS method are :

- A high level of reactive power circulates in the high frequency transformer when the operating point is significantly different to the nominal operating point.

- For phase shift modulation it is not possible to directly influence the shape of the transformer current since it depends on the DC voltages $V_{1}$ and $V_{2}$ as well as on the phase shift $\phi$. 


\section{Dr.R.Seyezhai / IOSR Journal of Engineering (IOSRJEN) \\ www.iosrjen.org}

Vol. 1, Issue 1, pp. 077-083

\section{B.Triangular Modulation}

Triangular modulation is used when the voltages $\mathrm{V}_{1}$ and $\mathrm{V}_{2}$ are significantly different. This modulation method can be implemented when the transformer has a turns ratio given by

$$
V 1 \ll V 2 / n
$$

The switching pattern for triangular modulation is shown in Fig.3.

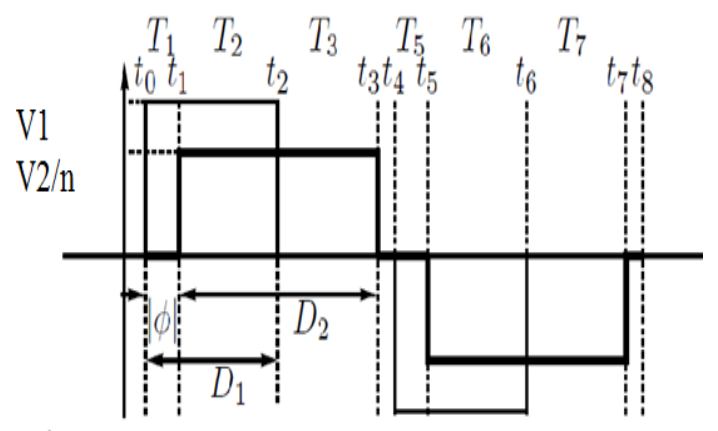

Fig.3 Switching pattern for triangular modulation

The advantages and disadvantage of triangular modulation are :

- This method allows for the implementation of ZCS for the low voltage side, which is desired for low switching losses, high switching speed, and low EMI.

- In this method the parasitic inductors of the low voltage side switches are utilized as part of the converter inductance $L$. It is particularly interesting for the specific converter because of the low value of $L$.

- Ineffective converter utilization.

\section{Trapezoidal modulation}

The trapezoidal modulation method can be implemented when the transformer has a turns ratio given by

$$
V 1 \approx V 2 / n
$$

The advantages of trapezoidal modulation are:

- Good converter efficiency is achieved. This is because the full bridge circuits are operating with large duty cycles and results in a lower RMS current than for triangular modulation.

- Switching losses are less compared to phase shift modulation.

The switching pattern for trapezoidal modulation is shown in Fig.4.

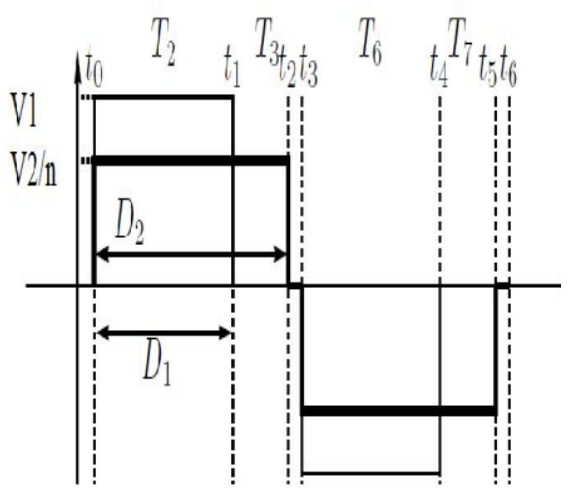

Fig.4 Switching pattern for trapezoidal Modulation

\section{DESIGN OF HIGH FREQUENCY TRANSFORMER}

The optimum design of a high-power and highfrequency transformer [8,9], which means

1) selection of the smallest standard core shape relevant to the throughput power, frequency, and transformer operating temperature,

2) calculation of the optimum flux density providing minimum transformer loss and

3) calculation of the optimum wire diameters of the windings.

The design equations are given from which the area of the core, window spacing, primary and secondary turns are determined. Assuming emf per turn $E_{t}=7.5 \mathrm{~V}$, the output KVA is calculated from the equation,

$Q=2.22 f K_{w} A_{w} B_{m} A_{i} \delta * 10^{-3}$

where $\delta=2.2 \mathrm{~A} / \mathrm{mm}^{2}$

$B_{\mathrm{m}=1.55 \mathrm{~Wb} / m^{2}}$ 


\section{Dr.R.Seyezhai / IOSR Journal of Engineering (IOSRJEN)}

www.iosrjen.org

$\mathrm{f}=20 \mathrm{khz}$

Vol. 1, Issue 1, pp. 077-083

\section{f $=20 \mathrm{khz}$}

$\emptyset_{m}=E_{t / 4} 44 f$

$K_{W}=10 /(30+K V$ of $H V)$

$A_{i}=\emptyset_{m} / B_{m}$

The area of the window is determined from the values obtained above,

$$
A_{w}=Q / 2.22 f K_{w} B_{m} A_{i} \delta * 10^{-3}
$$

Thus the net gross section area is obtained as given

$A_{g i}=\frac{A_{i}}{\text { Stackingfactor }}$

where stacking factor is assumed as 0.9. The transformer secondary turns are calculated using,

$$
T_{s}=E_{s} \cdot E_{\mathrm{t}}
$$

The primary turns for the transformer is determined as

$$
T_{p}=E_{p} \cdot \frac{T s}{E_{s}}
$$

Thus from the above equations the high frequency transformer design values are obtained and are shown in table 1.

Table 1 Design Equations for high frequency transformer

\begin{tabular}{|l|c|c|}
\hline \multicolumn{1}{|c|}{ Parameter } & Notation & Value \\
\hline $\begin{array}{l}\text { Height of the } \\
\text { window }\end{array}$ & $\mathrm{Hw}$ & $40 \mathrm{~mm}$ \\
\hline $\begin{array}{l}\text { Width of the } \\
\text { window }\end{array}$ & $\mathrm{Ww}$ & $18.2 \mathrm{~mm}$ \\
\hline $\begin{array}{l}\text { No of primary } \\
\text { turns }\end{array}$ & $\mathrm{Tp}$ & 8 turns \\
\hline $\begin{array}{l}\text { No of } \\
\text { secondary } \\
\text { turns }\end{array}$ & Ts turns \\
\hline
\end{tabular}

\begin{tabular}{|l|l|l|}
\hline $\begin{array}{l}\text { Width of the } \\
\text { flux path }\end{array}$ & A & $7.78 \mathrm{~mm}$ \\
\hline
\end{tabular}

Fig. 5 shows the design model of high frequency transformer.

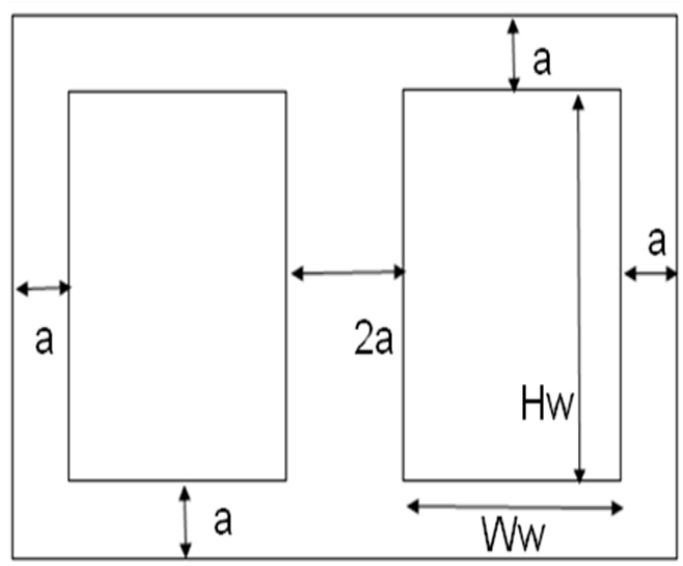

Fig.5.Design model of high frequency transformer

\section{EVALUATION OF PERFORMANCE PARAMETERS FOR DAB DC-DC CONVERTER}

The output voltage ripple and switching losses are evaluated for the three modulation strategies[10,11]mentioned in section-II. SIMULINK model of DAB DC-DC converter is shown in Fig.6.

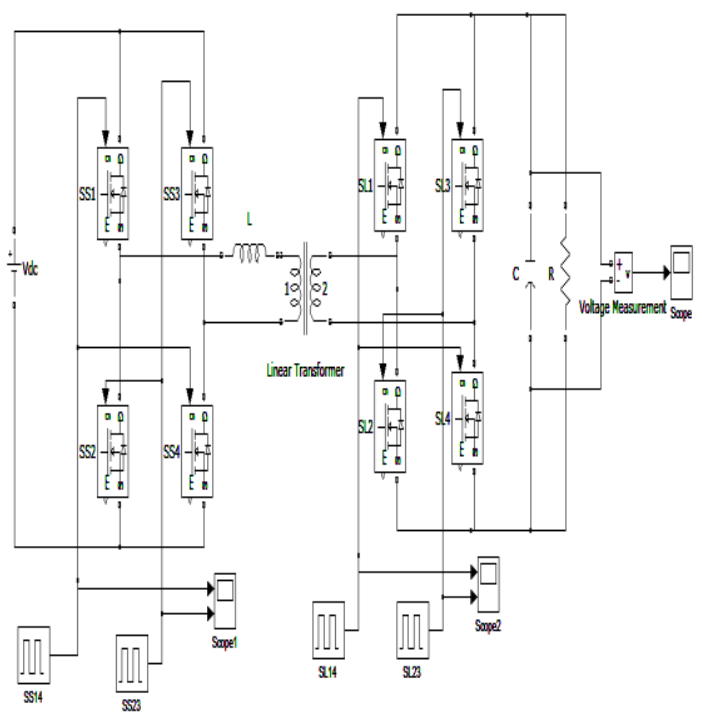




\section{Dr.R.Seyezhai / IOSR Journal of Engineering (IOSRJEN) \\ www.iosrjen.org}

Vol. 1, Issue 1, pp. 077-083

Fig.6 SIMULINK model of DAB DC-DC

Converter

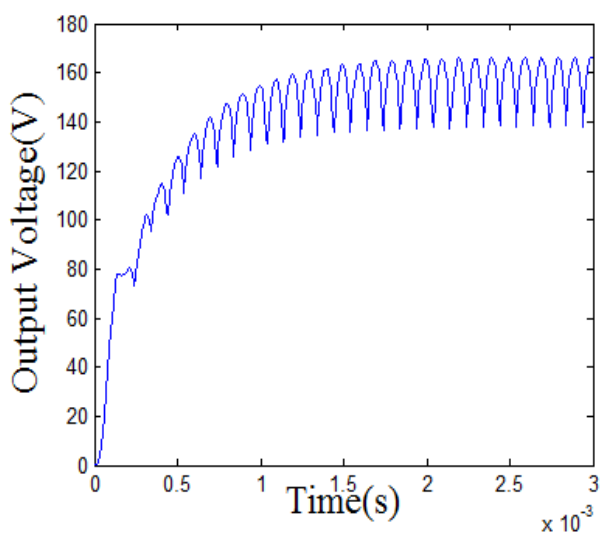

Fig.7. Output voltage ripple waveform for PS method of DAB

The output voltage ripple waveform for triangular method is shown in Fig.8.

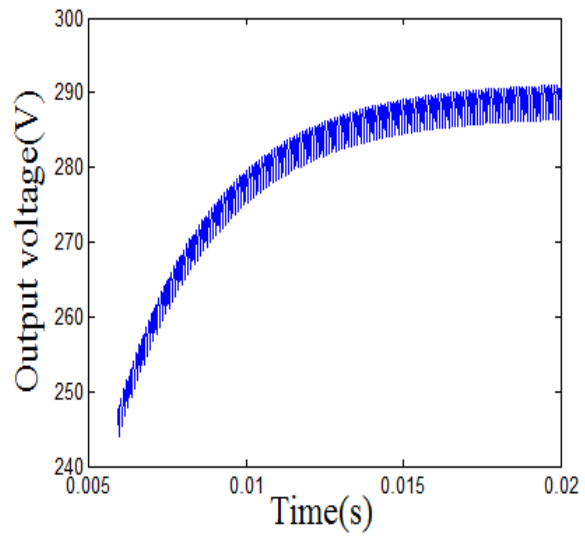

Fig.8 Output voltage ripple waveform For Triangular method for DAB

The output voltage ripple waveform for triangular method is shown in Fig.9.

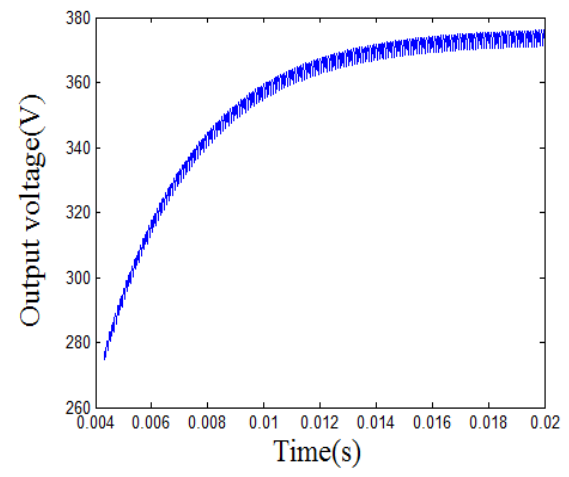

The output voltage ripple waveform for PS method is shown in Fig.7.

Fig.9 Output voltage ripple waveform For Triangular method for DAB

The output voltage ripple waveform is compared for all the modulation techniques which is shown in Table -II.

Table II Comparison of output voltage ripple of DAB

\begin{tabular}{|l|c|}
\hline Type of modulation & $\begin{array}{c}\text { Output voltage } \\
\text { ripple }\end{array}$ \\
\hline Phase shift & $1.89 \%$ \\
\hline Triangular & $0.15 \%$ \\
\hline Trapezoidal & $0.13 \%$ \\
\hline
\end{tabular}

The secondary current of the three modulating techniques is given in the Figs $10,11 \& 12$.

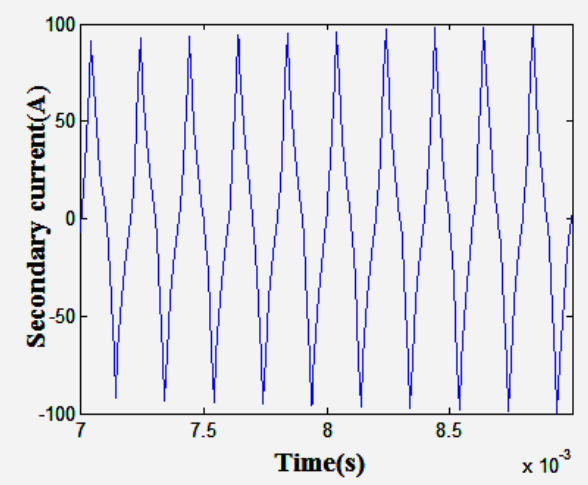

Fig.10. Secondary current waveform for PS method 


\section{Dr.R.Seyezhai / IOSR Journal of Engineering (IOSRJEN) \\ www.iosrjen.org}

Vol. 1, Issue 1, pp. 077-083

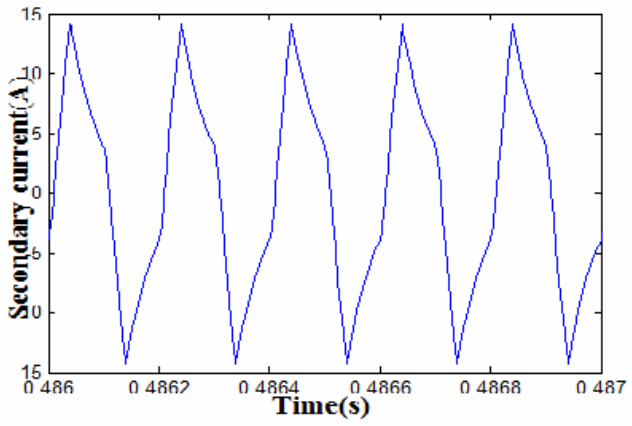

Fig.11. Secondary current waveform for triangular method

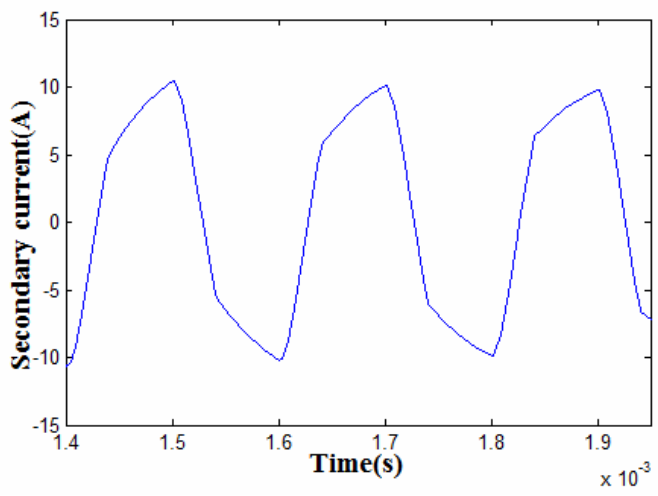

Fig.12. Secondary current waveform for trapezoidal method

The switching circuit for an IGBT and a diode is shown below

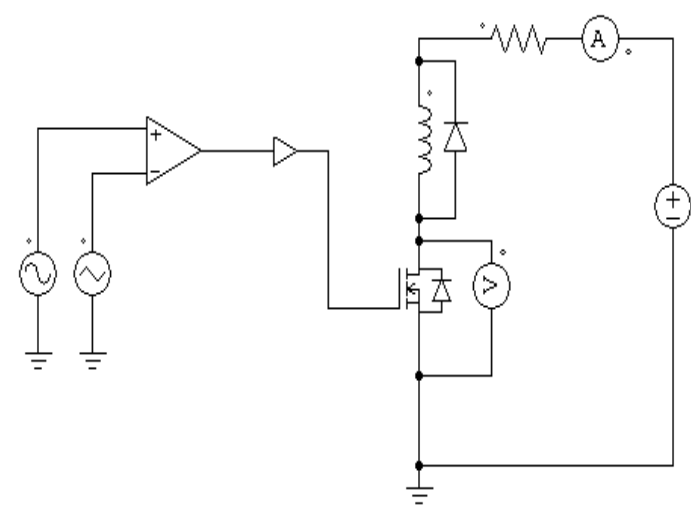

Fig.13 IGBT Switching circuit
The equations governing the calculation of switching loss for an IGBT are discussed as follows.

$$
\begin{aligned}
& \mathrm{E}_{\mathrm{on}}={ }_{0}{ }^{\mathrm{ton}} \mathrm{P}(\mathrm{t}) \cdot \mathrm{dt}=(1 / 2) \cdot \mathrm{V}_{\mathrm{CE}} \cdot \mathrm{I}_{\mathrm{C}} \cdot \mathrm{t}_{\mathrm{on}} \\
& \mathrm{E}_{\text {off }}={ }_{0} \int{ }^{\text {toff }} \mathrm{P}(\mathrm{t}) \cdot \mathrm{dt}=(1 / 2) \cdot \mathrm{V}_{\mathrm{CE}} \cdot \mathrm{I}_{\mathrm{C}} \cdot \mathrm{t}_{\mathrm{t} f f} \\
& \mathrm{E}_{\mathrm{sw}}=\mathrm{E}_{\text {on }}+\mathrm{E}_{\text {off }}=(1 / 2) \cdot \mathrm{V}_{\mathrm{CE}} \cdot \mathrm{I}_{\mathrm{C}} \cdot\left(\mathrm{t}_{\mathrm{on}}+\mathrm{t}_{\mathrm{off}}\right)
\end{aligned}
$$

The switching loss of an IGBT is calculated from the equation

$$
P_{s w}=f_{s w} \cdot E_{s w}
$$

Using the above equations, the switching loss is calculated for the various modulation strategies which is shown in table III.

\section{Table III Switching loss Calculation}

\begin{tabular}{|l|c|}
\hline Modulation technique & Switching losses \\
\hline Phase shift modulation & $50.92 \mathrm{~mJ}$ \\
\hline Triangular modulation & $46.51 \mathrm{~mJ}$ \\
\hline $\begin{array}{l}\text { Trapezoidal } \\
\text { modulation }\end{array}$ & $44.51 \mathrm{~mJ}$ \\
\hline
\end{tabular}

From Table III, it is found that the switching loss of the trapezoidal modulation is lower and the output voltage ripple (table II) is found to be lower .Therefore, trapezoidal modulation can be employed for DAB DC-DC converter for better performance.

\section{V.CONCLUSION}

A dual active bridge DC-DC converter has been investigated for renewable energy applications. Various modulation strategies for dual active 


\section{Dr.R.Seyezhai / IOSR Journal of Engineering (IOSRJEN) \\ www.iosrjen.org}

Vol. 1, Issue 1, pp. 077-083

bridge DC-DC converter has been analyzed. It is found that the trapezoidal modulation provides a lower output voltage ripple and reduced switching losses compared to other methods. The design of high frequency transformer has been discussed .From the simulation results, it is observed that the trapezoidal modulation is a better choice for DAB DC-DC converter.

\section{REFERENCES}

1. Tao, H. Kotsopoulos, A. Duarte, J.L , Hendrix .(2006) 'Family of multiport bidirectional DC-DC converters', Proceeding IEEE Power Electronics Applications, Vol. 153, No. 3, pp. 451-458.

2. Inoue, S. and Akagi, H.(2007) 'A bidirectional isolated dc-dc converter as a core circuit of the next-generation mediumvoltage power conversion system', IEEE Transactions on Power Electronics, Vol. 22, pp. 535 - 542.

3. Napoli, A.D. Crescimbini, F, Rod, S. Solero, L. (2002) 'Multiple input dc-dc power converter for fuel-cell powered hybrid vehicles', Proc. IEEE Power Electronics Specialist Conf., Vol. 4, pp.1685-1690.

4. Huang-Jen Chiu and Li-Wei Lin,(2007) 'A bidirectional $\mathrm{dc}-\mathrm{dc}$ converter for fuel cell electric vehicle driving system', IEEE Trans. Power Electron., Vol. 21, No. 4, pp. 950-958.

5. Kheraluwala, M.H. Gascoigne, R.W. Divan, D.M. Baumann, E.D. (1992) 'Performance characterization of a high-power dual active bridge dc-to-dc converter', IEEE Transactions on Industry Applications, Vol. 28, No. 6, pp. 1294-1300.

6. Kheraluwala, M.H. Wovotny, D. and Divan, D.M. (2000) 'Design considerations of high power high frequency transformers', IEEE-PESC Conference, Vol. 1,No. 4, pp734-742.

7. Oggier, G.G. Garcı, G.O. Oliva,A.R. (2009) 'Switching control strategy to minimize dual active bridge converter losses', IEEE Trans. Power Electron., Vol. 24,No. 7, pp. 1826-1838.

8. Petkov, R. and Hobson, L. (1992) 'Optimum design of a high frequency transformer', Proceedings of UPEC92, pp. 279-282.
9. Kheraluwala, M.H. Wovotny, D. and Divan, D.M. (2000) 'Design considerations of high power high frequency transformers', IEEE-PESC Conference, Vol. 1,No. 4, pp734-742.

10. Oggier, G. Guillermo, O. Garcia, and Alejandro, R. Oliva, (2010) 'Modulation Strategy to Operate the Dual Active

Bridge DC-DC converter Under SoftSwitching in the Whole Operating Range', IEEE Transactions Power Electronics, Vol. 1, No.6, pp. 1-9.

11. Krismer, F. Kolar, J.W. (2009) 'Accurate Power Loss Model Derivation of a HighCurrent Dual Active Bridge Converter for an Automotive Application', IEEE Transactions on Industrial electronics, Vol. 57, No. 3.pp. 881-999

\section{ACKNOWLEDGEMENTS}

The author wishes to express her gratitude to the management of SSN Institutions, Chennai, India for providing the computational facilities to carry out this work.

\section{BIOGRAPHY}

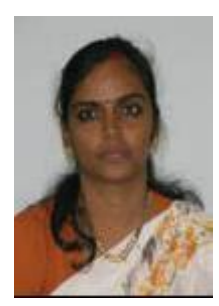

Dr.R.Seyezhai obtained her B.E. Electronics \& Communication Engineering) from Noorul Islam College of Engineering, Nagercoil in 1996 and her M.E in Power Electronics \& Drives from Shanmugha College of Engineering, Thanjavur in 1998 and Ph.D from Anna University, Chennai. She has been working in the teaching field for about 13 Years. She has published several papers in International Journals and International Conferences in the area of Power Electronics \& Drives. Her areas of interest include SiC Power Devices, Multilevel Inverters, Modeling of fuel cells, Design of Interleaved Boost Converter, Multilport DC-DC Converter and control techniques for DC-DC Converter. 